\title{
O DIREITO E A ÉTICA EM BENTHAM E KANT: UMA COMPARAÇÁO
}

\author{
Maria Cristina Longo Cardoso Dias
}

\begin{abstract}
RESUMO: Este trabalho tem como objetivo formular comparação entre as concepçōes de ética e direito dos autores Bentham e Kant. A posição assumida neste artigo ressalta que tanto para Kant quanto para Bentham o direito se baseia nos mesmos princípios que fundamentam a ética. No caso de Kant, é o imperativo categórico que fundamenta a ética e o direito e, no caso de Bentham, é o princípio de utilidade. Embora ambos os autores possuam apenas um princípio para fundamentar a ética e o direito, há inúmeras diferenças entre ambos os campos do pensamento, bem como entre as teorias, que se pretende apresentar neste artigo. Entre elas estão a origem epistemológica dos princípios e o que cada um deles prescreve.
\end{abstract}

PALAVRAS-CHAVE: Bentham. Dever. Direito. Ética. Kant.

\section{I- A teoria de Kant SObre a ÉTICA E O Direito}

Antes de entrar na comparação entre as teorias éticas e do direito de Bentham e Kant, é necessário identificar, primeiramente, qual a fundamentação que Kant atribui à moral. Para Kant, o predomínio do sujeito racional capaz de pensar uma metafísica que náo é derivada da experiência empírica torna essa matéria possuidora de conceitos denominados ideias que não se misturam a paixóes ou inclinaçóes. Disso resulta a autonomia e liberdade da vontade do indivíduo expressa pela necessidade de agir por dever a uma lei que ele próprio formula. A citação abaixo confirma a afirmação acima (KANT, 2001):

[...] não nos deve sequer passar pela ideia querer derivar a realidade deste princípio da constituiçáo particular da natureza humana. Pois o dever deve ser a necessidade prática-incondicionada da açáo; tem de valer portanto para todos os seres racionais (os únicos aos quais se pode aplicar sempre um imperativo categórico), e só por isso pode ser lei também para toda vontade humana. Tudo o que, pelo contrário, derive da disposição natural particular da humanidade, de certos sentimentos e tendências, mesmo até, se possível, duma propensão especial que seja própria da razão humana e não tenha que valer necessariamente para a vontade de todo o ser racional, tudo isso pode

\footnotetext{
${ }^{1}$ Professora Adjunta do Departamento de Filosofia da UFRN. Graduação, Mestrado e Doutorado pela FFLCH-USP. E-mail: crislongo@gmail.com.
} 
dar lugar para nós a uma máxima, mas não a uma lei; pode dar-nos um princípio subjetivo segundo o qual poderemos agir por queda ou tendência, mas não um princípio objetivo que nos mande agir mesmo a despeito de todas as nossas tendências, inclinaçóes e disposições naturais. Tanto assim, que a sublimidade e íntima dignidade do mandamento expresso num dever resplandecerão tanto mais, quanto menor for o apoio e mesmo quanto maior for a resistência que ele encontre nas causas subjetivas, sem que com isto enfraqueça o mínimo que seja a obrigaçáo que a lei impóe [...].

A lei prática derivada da razão é chamada de imperativo categórico, que versa sobre a ação segundo uma máxima que possa simultaneamente fazer-se a si mesma como lei universal².

O ser racional capaz de agir por obrigação (dever) à lei prescrita pelo imperativo categórico, independentemente de suas inclinaçóes, é dito livre. Ou seja, as açôes realizadas livres de qualquer inclinação por dever à lei derivada da razão (imperativo categórico) são consideradas éticas e morais. As leis derivadas da razão (imperativo categórico) que originam ações, as quais, contudo, não exigem o incentivo do dever para serem realizadas são jurídicas e morais. As leis da liberdade ou morais são assim chamadas para distinguir-se das leis da natureza ${ }^{3}$. As leis (conforme descrito no parágrafo IV da metafísica dos costumes ${ }^{4}$ ), sejam elas internas, sejam externas, devem possuir dois elementos:

\section{A lei que representa uma ação faz dessa ação um dever.}

\section{A escolha subjetiva para agir segundo a lei necessita de um incentivo.}

${ }^{2}$ KANT (2001) assinala que “[...] o imperativo categórico é, portanto, só um único, que é este: Age apenas segundo uma máxima tal que possas ao mesmo tempo querer que ela se torne lei universal”.

${ }^{3}$ BOBBIO (1997) afirma: "O homem como ser analisável do ponto de vista fenomenológico está submetido às leis da natureza, que regulam a vida de todos os outros seres naturais; mas, enquanto ser livre, pertencente ao mundo inteligível, o homem foge das leis naturais e adequa suas açôes a uma forma diferente de legislaçâao: a legislação moral, que dá origem ao mundo dos costumes, em contraposição ao mundo natural [...]".

${ }^{4}$ KANT (1991) ressalta: 'In all lawgiving (whether it prescribes internal or external actions, and whether it prescribes them a priori by reason alone or by choice of another) there are two elements: first, a law, which represents an action that is to be done as objectively necessary, that is, which makes the action a duty; and second, an incentive, which connects a ground for determining choice to this action subjectively with the representation of law". Traduçấo livre: "Em toda lei promulgada (se prescreve açôes internas ou externas, e se as prescreve a priori apenas pela razão ou pela escolha de outro fator) existem dois elementos: primeiro, uma lei que representa uma ação que precisa ser feita de maneira objetivamente necessária, isto é, torna a ação um dever, e segundo: um incentivo que conecta o fundamento para determinar a escolha por essa ação, subjetivamente, com a representação da lei”. 
A lei que faz dessa ação um dever e também faz deste dever um móbil é ética. Ao contrário, a lei que faz dessa ação um dever, mas que não inclui necessariamente o incentivo do dever nela e, portanto, admite outro móbil, é chamada jurídica.

Disto se depreende que a conformidade da ação com a lei, sem que o agente faça de sua intenção o dever, é chamada legalidade jurídica. Porém, quando a ideia de dever é também o incentivo da ação, a lei é chamada ética. Deveres que estấo de acordo com as leis do direito são deveres externos, uma vez que a lei de direito não exige que a concepção interna de dever seja o fundamento determinante da escolha do indivíduo.

O incentivo que concerne à ação no campo do direito pode ser a coação, ao contrário da ética. Esta última prescreve, por exemplo, que se deve cumprir um contrato em que alguém se comprometeu, mesmo se a outra parte envolvida não se utilizar da coaçáo. Por conseguinte, o campo do cumprimento de leis jurídicas é o direito e não a ética, uma vez que se não estivessem no campo jurídico, todos dependeriam da boa vontade alheia para a manutenção dos princípios do direito.

A doutrina do direito não é distinta, pois, da doutrina da ética pelos seus deveres, mas pela diferença na motivação de ambas as leis. Ou seja, a ética não tem em comum com o direito a forma da obrigaçáo.

O princípio universal do direito é então descrito da seguinte forma: qualquer ação é livre se pode coexistir com a liberdade de outro, segundo uma lei universal, ou se a máxima de liberdade de escolha de um pode coexistir com a liberdade de todos, de acordo com uma lei universal.

Essa máxima, contudo, não é interna, para o direito. A lei universal do direito ressalta que se deve agir de forma que o livre uso da escolha de alguém possa coexistir com a liberdade de todos, segundo uma lei universal. Em outras palavras, há uma obrigação que recai sobre o agente, embora tal indivíduo não precise ter como móbil da ação a intenção de agir de acordo com essa obrigação.

Apesar da forma de obrigação do direito ser independente da intenção de agir por dever, o princípio universal do direito continua a ser embasado pela moral, pois o direito, através da coação, constitui uma forma de garantir que a lei prescrita pelo imperativo categórico (o qual expressa a realização de uma ação segundo uma máxima que possa simultaneamente fazer-se a 
si mesma como lei universal) seja cumprida, garantindo, assim, a liberdade externa dos indivíduos.

Dessa maneira, o fundamento da moral, que não é senão outro além da lei prescrita pela razão (imperativo categórico), serve tanto para embasar a ética quanto o direito. Este último garante, através da coação, que a autonomia da vontade dos seres racionais seja cumprida.

A forma de obrigação do direito que é externa ao indivíduo (coação) se faz necessária, porque, considerando as qualidades sensíveis dos homens, não se pode esperar que todos eles concordem autonomamente em viver sob as regras de uma constituição legal em consonância com os princípios da livre vontade 5 . Portanto, o direito constitui apenas a forma de garantir a coexistência da liberdade externa dos indivíduos, que, contudo, náo deixa de ser fundamentada pela moral e ditada pela razão.

Existem autores, como Bobbio ${ }^{6}$ (1995), que separam a moral do direito, argumentando que a primeira trata da ação cumprida por dever (dessa forma, é embasada pelo imperativo categórico e constitui a autonomia da vontade) e a segunda corresponde a uma ação conforme o dever, com outros motivos e inclinaçóes distintos da noção de dever (e, por isso, seria embasada pelo imperativo hipotético constituindo heteronomia, ao invés de autonomia da vontade). É fato que um indivíduo, quando age de acordo com as normas jurídicas, não precisa ter como incentivo da ação o dever, todavia, ainda que não tenha por incentivo da ação o dever, sua ação acaba sendo embasada pela prescrição do imperativo categórico, pois pode ser universalizada. Em outras palavras, ainda que o indivíduo náo deseje que sua ação seja universalizada, por ter outro móbil para a ação diverso do dever, ao agir conforme leis jurídicas que observam o imperativo categórico, transforma suas açōes em máximas universais que são distintas das simples ações conforme o imperativo hipotético, já que garantem a liberdade externa dos indivíduos e a autonomia da vontade dos seres racionais. Assim, tudo que o pensamento de Bobbio ensina quanto a este tema é que a forma de obrigação do direito é diferente da

${ }^{5}$ KANT (1974) assinala: [...] "Como, por conseguinte, a esta diversidade das vontades particulares de todos deve-se ainda acrescentar uma causa unificadora delas, para engendrar uma vontade comum, o que nenhum dentre todos pode conseguir, não se pode contar, para a execução daquela ideia (na prática), com nenhum outro começo da condição legal senão o começo pela força, sobre cuja coação posteriormente será fundado o direito público".

${ }^{6}$ BOBBIO (1995) afirma que, “[...] rigorosamente, deveríamos então admitir sem necessidade de uma prova ulterior que, uma vez atribuída a qualificação de heterônoma à vontade jurídica, seja possível atribuir a qualificação de hipotético ao imperativo jurídico". 
forma de obrigação da ética e, nesse ponto, este artigo concorda com o autor; no entanto, apesar de seu pensamento, não há a exclusão da possibilidade de que o direito seja fundamentado pela moral, porque a razão prática é uma só e instrui ambos os temas. Terra (2004) ressalta:

Direito e virtude participam da doutrina dos costumes e têm os mesmos fundamentos últimos, o que é consequência da unidade da razão prática, pois as duas legislaçôes são provenientes da autonomia da vontade. Esta é o fundamento das duas legislaçóes; o princípio supremo da doutrina dos costumes é o imperativo categórico.

Tendo em vista que a razão prática é uma só e seu princípio derivado que rege a doutrina dos costumes é também um só, a saber: o imperativo categórico, considerando que todos os seres humanos são racionais, resta possível depreender um estatuto de universalidade a essa lei formal da razáo. Cabe notar, porém, que esse estatuto de universalidade só pode ser atestado, caso se aceite a noção de racionalidade pura e prática descrita por Kant.

Assim, assumido o embasamento das leis jurídicas pela moral, Kant destaca que não há por que afirmar que a teoria não possa ser realizada na prática ${ }^{7}$. Para Kant, está claro que a política é a doutrina do exercício do dever e que não pode haver conflito entre a moral e a política ${ }^{8}$.

$\mathrm{O}$ autor afirma que a forma de implementar os princípios do direito na esfera pública se dá a partir da utilização da política como um instrumento de sua administraçáo. Ou seja, a política serve para colocar em prática os princípios do direito ditados pela moral.

Quanto mais a vontade dada a priori (princípio formal) estiver independente do objeto da livre vontade (finalidade), melhor e mais facilmente será atingida uma das finalidades da razão prática, que se constitui no benefício da paz perpétua entre os Estados ${ }^{9}$. Assim, as máximas políticas

\footnotetext{
${ }^{7}$ KANT (1974) assevera: "A moral é já por si mesma uma prática no sentido objetivo, enquanto totalidade de leis que ordenam incondicionalmente, de acordo com as quais devemos agir, sendo um evidente absurdo alguém, depois de ter admitido a autoridade deste conceito do dever, querer dizer que não se pode realizá-lo".

${ }^{8}$ KANT (1974) declara: "Por conseguinte, não pode haver nenhum conflito entre a política, enquanto doutrina do exercício do dever, e a moral como tal, mas teórica (portanto nenhum conflito entre a prática e a teoria)."

${ }^{9}$ Escreve KANT (1974): "Procurai primeiramente o reino da razão pura e prática e sua justiça, e então vos será dada por si mesma vossa finalidade (o benefício da paz perpétua). Pois a moral tem em si
} 
não podem originar-se do bem-estar ou da felicidade de cada Estado, não derivando da finalidade que cada um deles estabelece como objeto do querer. Devem decorrer do conceito puro do dever do direito, quaisquer que venham a ser as consequências. Eis a perspectiva de Kant (1974):

É preciso principalmente uma constituição interior do Estado instituída de acordo com os puros princípios do direito, e em seguida também a uniáo dele com os Estados vizinhos ou mesmo distantes (análogo a um Estado universal), para se chegar a um ajuste legal de suas discordâncias. Esta proposição não quer dizer outra coisa senão isto: as máximas políticas não devem originar-se do bem-estar ou da felicidade de cada Estado [...] e por conseguinte náo derivam da finalidade que cada um deles estabelece como objeto (do querer), enquanto supremo (mas empírico) princípio da sabedoria política, e sim provir do conceito puro do dever do direito (da obrigação moral, cujo princípio a priori é dado pela razão pura), quaisquer que venham a ser as consequências físicas.

Por conseguinte, teoricamente, não existe nenhum conflito entre a moral e a política. Os princípios do direito podem ser levados à prática e conservados por parte do povo, no Estado, e por parte dos Estados uns com relação aos outros, independentemente do que a política empírica objete contra isso.

Portanto, a verdadeira política não pode ser aplicada sem antes se consultar aquilo que os princípios do direito e da moral têm a ensinar ${ }^{10}$. No que concerne ao papel da moral na história, é importante que seja esclarecido o significado de ideal, para esse autor. Pode-se sustentar que a concepção de ideal ${ }^{11}$ constitui, para ele, um protótipo perfeito irrealizável determinado

a particularidade, até mesmo no que respeita a seus princípios de direito público (por conseguinte com relaçáo a uma política capaz de ser conhecida a priori), de quanto menos torna dependente o comportamento da finalidade pré-estabelecida, da vantagem visada, seja ela física ou moral, tanto mais, contudo, concorda em geral com esse fim".

${ }^{10}$ KANT (1974) afirma que "[...] não se pode aqui proceder a uma divisão em partes iguais, e inventar o termo médio de um direito pragmaticamente condicionado (situado entre o direito e as vantagens), porém toda política está obrigada a dobrar os joelhos ao direito, podendo em compensação esperar chegar, embora lentamente, a um grau em que brilhará permanentemente”.

${ }^{11}$ Conforme KANT (1989), “[...] temos de confessar que a razão humana contém não só ideias, mas também ideais que, embora não possuam força criadora como os de Platão, têm no entanto força prática (como princípios reguladores) e sobre eles se funda a possibilidade de perfeição de certas açôes" [...] "A virtude, e com ela a sageza humana, em toda a sua pureza, são ideias. Mas o sages (do estóico) é um ideal, isto é, um homem que só no pensamento existe, mas que coincide inteiramente com a ideia da sageza. "Assim como a ideia dá a regra, assim o ideal, nesse caso, serve 
pela ideia, mas que requer um andamento em direção a esta noção. $\mathrm{O}$ ideal do sistema de Kant, do ponto de vista do direito, é a construção de uma constituição perfeita que siga os princípios jurídicos ancorados na moral.

Tais princípios levados à prática, através da política, dentro de um Estado para com seu povo, e nas relaçôes entre vários Estados, levariam ao propósito da paz perpétua. À medida que o esclarecimento e a cultura progredissem rumo a permitir que a constituição se aproximasse dos princípios do direito fundados na moral, poderia ser verificado o avanço jurídico na história ${ }^{12}$. Contudo, esse ideal, de acordo com a definição de Kant, é irrealizável, mas segue um caminho progressivo, ao longo da história.

Kant defende a incessante busca pela reforma da constituição para aproximá-la de seu ideal de perfeição ${ }^{13}$ (constituição de princípios jurídicos fundados na moral). Desse modo, mesmo que se observe que individualmente a maioria dos homens aja de forma patológica segundo suas inclinaçóes egoístas, verifica-se, historicamente, um progresso jurídico da sociedade rumo aos princípios do direito, ancorados na moral.

\section{II- A teoria de Bentham Sobre a Ética e o direito}

No que diz respeito ao utilitarismo de Bentham, muitos elementos de sua teoria são diferentes da teoria kantiana. De acordo com esse autor, o princípio de utilidade, fundador das noçôes de moralidade e justiça, em seu sistema, deve ser conforme uma noção de natureza humana verificada empiricamente. Tal natureza pressupóe que os homens estáo sob o domínio de dois senhores soberanos, a saber: o prazer e a dor, os quais ditam tudo que o homem deve fazer como o que fará, na realidade. Bentham (1973, itálico nosso) assinala:

[...] não estamos aqui diante de uma teoria nova e pouco segura, ou inútil. Com efeito, tudo quanto acabamos de expor representa um dado com

de protótipo para a determinação completa da cópia e não temos outra medida das nossas açôes que náo seja o comportamento deste homem divino em nós, com o qual nos comparamos, nos julgamos e assim nos aperfeiçoamos, embora nunca o possamos alcançar." [...] "Eis o que se passa com o ideal da razão, que deverá sempre assentar em conceitos determinados e servir de regra e de modelo quer para a açẫo, quer para o juízo de apreciação".

${ }^{12}$ KANT (1974) salienta que "[...] a providência está assim justificada no curso do universo, pois o princípio moral no homem nunca se extingue; a razão do direito de acordo com aquele princípio cresce ainda mais constantemente por motivo da cultura que progride sempre".

13 Cabe mencionar que Kant rejeita a noçấo de revoluçấo, visto que, para ele, esta substitui despoticamente antigos preconceitos por novos. 
o qual concorda plena e perfeitamente a experiência do gênero humano, onde quer que os homens possuam uma visão clara acerca dos seus próprios interesses.

É relevante notar que, no sistema de Bentham, prazer é sinônimo de bem e dor é sinônimo de mal. Os prazeres e as dores são os únicos bens e males em si, respectivamente. Todos os outros elementos relacionados a indivíduos podem ser ditos bens ou males, figurativamente, apenas na medida em que possuem relação com a geração de prazer ou dor.

Por ser conforme uma noçáo de natureza humana que busca o prazer e foge da dor, verificada empiricamente, o princípio de utilidade não entende que seja necessário haver a supressão das inclinações humanas para que a ação seja moral. Ao contrário, ele reconhece que os homens agem de acordo com determinadas finalidades, segundo seus interesses, e coloca como norma que os indivíduos busquem seu prazer ou seus interesses ${ }^{14}$. Sendo assim, o princípio da utilidade é formulado da seguinte forma:

Bentham (1973) afirma: Por princípio da utilidade entende-se aquele princípio que aprova ou desaprova qualquer ação, segundo a tendência que tem a aumentar ou a diminuir a felicidade da pessoa cujo interesse está em jogo, ou, o que é a mesma coisa em outros termos, segundo a tendência a promover ou a comprometer a referida felicidade. Digo qualquer açáo, com o que tenciono dizer que isto vale não somente para qualquer ação de um indivíduo particular, mas também de qualquer ato ou medida de governo [...]. Ou, em outros termos, o princípio da utilidade é explicado da seguinte forma; [...] O princípio que estabelece a maior felicidade de todos aqueles cujo interesse está em jogo, como sendo a justa e adequada finalidade da ação humana, e até a única finalidade justa, adequada e universalmente desejável; da ação humana, digo, em qualquer situação ou estado de vida, sobretudo na condiçấo de um funcionário ou grupo de funcionários que exercem os poderes do governo [...].

Da mesma forma que Kant, a teoria moral de Bentham visa à universalidade, ao atestar que todos os indivíduos buscam o prazer e fogem da dor e que assim devem fazer, porque é o que todos querem, porque é a razão de existência de todos. $\mathrm{O}$ critério epistemológico para realizar tal afirmaçáo é indutivo, ou seja, é a partir da observação de uma multidão de indivíduos

${ }^{14}$ Embora entenda melhor o princípio da utilidade aquele que leve em conta em seus interesses, os interesses de todos os afetados por uma ação. 
que se pode atestar que os mesmos buscam o prazer e fogem da dor e desejam agir assim. Tal critério poderia ser indagado como não sendo capaz de gerar enunciados universais, visto que, apesar de todos os indivíduos serem passíveis de serem observados (pois seu número é finito), não é possível afirmar que o próximo indivíduo que ainda não existe, mas existirá, agirá dessa mesma forma, antes de observá-lo. Nesse caso, há sempre a possibilidade de essa regra não ser universal, em um sentido lógico, porém, em um sentido prático, ela funciona como se fosse universal até que surja um novo elemento que a refute, como o nascimento de alguém que não busca prazer e não se afasta da dor.

Considerando que nenhum caso até o presente momento refuta a tese hedonista (de que os homens buscam o prazer e fogem da dor), temse, dessa forma, que não há casos que refutem a universalidade do princípio de utilidade. Tendo em vista a definição do princípio descrita acima, são considerados morais, portanto, os indivíduos que buscam seus prazeres ou seus interesses, ressaltando que aqueles que levam em conta os outros afetados por um ato e, nesse sentido, as consequências de uma açáo, agem mais de acordo com o princípio da utilidade. Atos ruins ou imorais são aqueles que não estão de acordo com a maximização de prazer ou geram a maximização de dor dos indivíduos.

A partir da análise da formulação do princípio de utilidade, é possível depreender que ele possui um duplo aspecto: um aspecto individual e um aspecto coletivo. $\mathrm{O}$ aspecto individual, da primeira formulação do princípio da utilidade, aprova que o indivíduo busque o seu prazer ou sua diminuição de dor, enquanto o aspecto coletivo do princípio aponta para a maximizaçáo de prazer e minimização de dor de todos os afetados por uma ação.

$\mathrm{O}$ aspecto coletivo deve ser observado, principalmente, por um membro do governo capaz de coibir os indivíduos que geram mais dor do que prazer aos membros de uma comunidade. $\mathrm{O}$ âmbito da possibilidade da geração de dor é o próprio escopo do direito, da lei penal. A ética, para Bentham, referese, predominantemente, ao domínio das açóes em que os indivíduos têm a possibilidade de gerar prazer uns aos outros ${ }^{15}$ (beneficência), bem como ao

\footnotetext{
15 Para BENTHAM (1843b), "[...] as the rules of beneficence, these, as far as concern matters of detail, must necessarily be abandoned in great measure to the jurisdiction of private ethics [...]". Tradução livre: "[...] como as regras da beneficência, estas, no que tange a assuntos de detalhe, devem ser abandonadas em grande medida à jurisdição da ética privada [...]”.
} 
campo em que há ação, mas não há interação entre os indivíduos ${ }^{16}$ (ramo da prudência). Enfatiza Bentham (1973):

A parte da missão do governo que consiste em punir constitui mais particularmente o objeto da lei penal. A obrigatoriedade ou necessidade de punir uma ação é proporcional na medida em que tal ação tende a perturbar a felicidade e na medida em que a tendência do referido ato é perniciosa, [...] Como temos visto, o escopo geral de todas as leis é evitar o prejuízo, isto é, quando valer a pena [...].

No utilitarismo de Bentham, tanto a ética quanto o direito possuem instrumentos de coação. No que concerne à ética, a coação acontece quando um membro de destaque da comunidade desaprova determinada ação, pelo fato de ter proporcionado mais dor do que prazer, no cômputo do balanço entre prazer e dor ${ }^{17}$. No caso do direito, a forma de coação mais efetiva que existe é a punição legal.

Embora o campo de atuação da punição seja o campo da geração de injúrias entre indivíduos, para alguns casos desse tipo não há a necessidade de sua formulação, visto que a própria punição ocasiona dor. Dessa forma, a punição necessita de satisfatórias razões para sua existência, sendo necessário que a punição proporcione um benefício, prazer ou diminuiçâao de dor maior à comunidade do que a dor que gera pela sua aplicação. Esclarece Bentham (1973):

[...] acontece, porém, que toda puniçáo constitui um ato pernicioso; toda puniçáo constitui, em si mesma, um mal. Por conseguinte, com base no princípio da utilidade - se tal princípio tiver que ser admitido-, uma punição só pode ser admitida na medida em que abre chances no sentido de evitar um mal maior.

${ }^{16}$ BENTHAM (1843b) afirma: "[...] of the rules of moral duty, those which seem to stand least in need of the assistance of legislation, are the rules of prudence. [...] It is plain, that of individuals the legislator can know nothing: concerning those points of conduct which depend upon the particular circumstances of each individual, it is plain, therefore, that he can determine nothing to advantage [...]”. Traduçáo livre: “[...] das regras do dever moral, aquelas que parecem precisar menos da necessidade de assistência da legislação são as regras da prudência. [...] É manifesto que o legislador náo pode saber nada sobre os indivíduos no que concerne àqueles pontos da conduta que dependem de circunstâncias particulares de cada indivíduo, é vidente, portanto, que ele não pode determinar nada de vantajoso". É importante notar que prudência, para Bentham, significa o campo do agir dos indivíduos em que não há interação. Seriam as regras de conduta individual da vida.

${ }^{17}$ BENTHAM (1973) sublinha: "Se o prazer e a dor estiverem nas mãos de pessoas que por acaso ocupam um lugar de destaque na comunidade, segundo a disposição espontânea de cada pessoa, e não de acordo com alguma regra estabelecida ou acordada, podemos dizer que o prazer e a dor derivam da sanção moral ou popular". 
Quando a possibilidade de formular punição demonstra que mais dor será gerada do que o benefício ou prazer auferido a partir de sua aplicaçáo, a ação capaz de gerar injúrias deve ser mantida sob o escopo da ética. A ética, com base em seu instrumento de coação, deve ficar responsável pela desaprovação de açóes capazes de gerar injúrias, quando não compensar a aplicação de punição.

Os casos em que há geração de dor, mas em que a punição não deve ser aplicada, são aqueles em que a punição é infundada, ineficaz, excessivamente onerosa e supérflua ou desnecessária ${ }^{18}$. A punição é infundada, quando se pretende aplicá-la a uma ação que não gerou mal no todo; em outras palavras, $\mathrm{o}$ ato pode ter gerado mal, mas não merece punição, porque a ação gera mais prazer do que dor, no cômputo do balanço. A punição é dita ineficaz, quando sua formulação não impede a geração de um prejuízo, apenas somando-se a ele.

Salientar que a aplicação da pena é excessivamente onerosa significa que o mal causado pela punição se adicionará ao mal que se quer impedir, sem que um benefício suficiente seja gerado, como, por exemplo, nos casos em que os serviços penais se tornam extremamente onerosos, privando a comunidade de se beneficiar de outros serviços estatais.

Quando o propósito de colocar um fim a uma determina ação pode ser atingido a uma taxa mais barata do que adotando a puniçấo legal, diz-se que a punição é supérflua ou desnecessária. Esses são os casos em que se pode impedir o mal pela instrução, informando o entendimento, ou pela coação ética ou por algum outro tipo de influência direta na vontade. De acordo com Bentham, para esses casos, é necessário agir com a caneta e não com a espada.

É interessante notar que, para esses quatro casos em que um mal é gerado, é sempre o princípio da utilidade, através de um balanço entre prazer e dor, que recomenda a não intervenção da punição legal, pois sua aplicação geraria um mal, somando-se ao mal da ofensa, sem que um benefício suficiente fosse ocasionado, embora o campo da punição seja, em geral, o domínio da geração de injúrias.

Para os casos em que não cabe punir legalmente, todavia, nos quais há geração de mal, afirma-se que ficam sob o escopo da ética, podendo estar sujeitos a uma punição moral derivada do instrumento de coação presente na

${ }^{18}$ BENTHAM, 1973, p.65. 
ética, a saber: a desaprovação de alguém que espontaneamente ocupe um lugar de destaque na comunidade.

Resta claro, portanto, que, no utilitarismo de Bentham, seja no campo da ética, seja no campo do direito, a finalidade das açôes deve sempre ser levada em conta, através da aplicação do princípio da utilidade, por meio do balanço entre prazer e dor. Caso mais dor do que prazer seja gerado, o princípio da utilidade apontará para a aplicação da punição legal, podendo indicar que esta náo deve ser formulada, quando ocorrer algum dos quatro casos descritos acima.

Por isso, o campo da ética fica circunscrito, em primeiro lugar, à maioria das ações em que há interação entre indivíduos e a tendência do ato é boa; isto quer dizer que a ética diz respeito, em primeiro lugar, a atos que geram mais prazer do que dor, no cômputo do balanço entre prazer e dor ${ }^{19}$, porque deve estimular essas açóes por meio de seu instrumento de coação (sanção moral). Os casos que não envolvem interações entre indivíduos ficam igualmente sob o escopo da ética e nunca devem ser matéria de legislação, pois tratam das ações que os indivíduos têm para consigo, dizem respeito às regras de conduta individuais que, conforme ressaltado, ninguém conhece melhor do que os próprios agentes, uma vez que são eles que possuem uma ideia clara acerca da direção de suas vidas.

Compreendida a distinção entre ética e direito, a qual se refere, especialmente, à forma de coação entre ambos, bem como aos tipos de consequências das açôes, pois, caso as consequências pesem para a dor, a legislação deve ser aplicada, na maioria das vezes, quando as consequências das açôes pesarem para o prazer ou, quando não houver interaçôes entre indivíduos, a ética pode ser aplicada.

Contudo, seja no âmbito da ética, seja no âmbito do direito, as finalidades, as consequências ${ }^{20}$ das açóes constituem o ponto relevante da teoria utilitarista, porque apenas elas podem gerar prazer e dor - os únicos bens ou males em si. Em todos os casos, para todas as açôes, a maximização ${ }^{21}$ de prazer e a minimização de dor é recomendada pelo princípio da utilidade,

\footnotetext{
${ }^{19}$ Frise-se que, para alguns casos em que há interação entre indivíduos e a geração de prazer prevalece sobre a dor, pode-se aplicar legislaçáo, recompensando indivíduos que proporcionam casos exemplares para a comunidade.

${ }^{20}$ SINGER, 1977, p. 67.
}

21 WARKE, 2000, p. 3. 
estejam as ações no campo da ética, estejam elas no campo do direito. Em outras palavras, o princípio da utilidade é o fundamento da ética e do direito, havendo distinção apenas quanto ao tipo de coação que ambos os temas empregam.

Também baseado em seu princípio de utilidade, Bentham recomenda a paz entre as naçóes. Na perspectiva do autor, é por um cálculo norteado pelo balanço entre prazer e dor, benefício e custo, que as naçóes devem buscar a paz, porque a guerra ou a tentativa de manter o domínio sobre nações, em todos os casos, possuem consequências mais dolorosas do que prazerosas, em longo prazo. Essa recomendação está fundada no princípio da utilidade, assim como a ética e o direito.

É porque Bentham ressalta que a guerra é inútil (em oposição ao termo utilidade) que ela náo deve ser feita. $\mathrm{O}$ primeiro argumento do autor contrário à guerra sugere que o mais feliz dos homens em tempos de paz torna-se o maior sofredor em tempos de guerra ${ }^{22}$, destacando a intensidade do sofrimento que a guerra causa para os afetados por ela, versus o pequeno benefício para quem a provoca. Segundo o autor, o ataque e manutençáo de países (como colônias), tratados ofensivos ou defensivos entre potências, tratados de comércio e a manutenção de excessiva força militar são todos elementos que ocasionam desvantagens econômicas tanto para os países que os praticam quanto para os países afetados ${ }^{23}$. Os custos de manutenção de colônias ou países conquistados superariam amplamente os benefícios gerados pela posse desses países, provocando aumento de impostos nas naçóes conquistadoras. A manutenção de tratados ofensivos ou defensivos, ou aliança entre potências, seria responsável por gerar hostilidade por parte das naçóes náo pertencentes aos tratados e, portanto, a guerra; o mesmo ocorreria com os tratados de comércio.

Além disso, a manutenção de excessiva força militar ocasionaria hostilidade entre naçóes, causando uma situação de instabilidade e possibilidade de guerra, considerada inútil, por Bentham, tanto do ponto de vista econômico quanto do ponto de vista exclusivamente social. A guerra, para o autor, levaria a intensos sofrimentos por parte daqueles que participam dela e pelos afetados por ela, além de gerar elevação de impostos para os

\footnotetext{
${ }^{22}$ BENTHAM (2012) afirma que "[...] os mais felizes da humanidade são sofredores na guerra; e os mais sábios, o que digo, até os menos sábios são sábios o suficiente para atribuir o cerne de seus sofrimentos a essa causa”.

${ }^{23}$ BENTHAM, 2012, p. 167.
} 
membros dos países que a provocam. Ademais, a guerra, ao requerer recursos para sua efetivação, desviaria investimentos que poderiam ser integralmente aplicados no comércio ou em outras áreas.

Assim, para os três domínios do utilitarismo do autor -a ética, o direito e a política de paz entre naçóes - o aspecto relevante a ser levado em conta para avaliação das açôes são suas consequências, suas finalidades, o balanço entre prazeres e dores.

\section{III- Comparação entre as teorias de Bentham e Kant sobre o direito e a ÉTICA E CONCLUSÃo}

A partir das afirmaçóes sobre o utilitarismo de Bentham explanadas acima, é possível depreender que o princípio da utilidade é tanto o fundamento da ética quanto do direito, assim como, para Kant, o imperativo categórico constitui o fundamento da ética e do direito. Contudo, a origem de ambos os princípios é totalmente distinta: enquanto o imperativo categórico é uma lei formal derivada exclusivamente da razão, sem nenhuma interferência do homem empírico ou das consequências que pode ocasionar, o princípio da utilidade é um princípio conforme uma noção de natureza humana observada empiricamente. Não obstante as diferentes origens epistemológicas do imperativo categórico e do princípio de utilidade, ambas as teorias, com base em seus princípios que fundamentam a ética e o direito, aspiram à universalidade.

Em outras palavras, mesmo que o imperativo categórico constitua uma lei formal derivada exclusivamente da razão, sem nenhum interferência empírica na sua elaboração, e embora o princípio da utilidade seja derivado de uma lei científica observada empiricamente (segundo a qual os homens buscam prazer e fogem da dor), apesar de os métodos para auferir esses princípios que fundamentam tanto a ética quanto o direito serem distintos, ambos buscam ser universais, ambos têm a necessidade de possuir estatuto de únicos princípios válidos para reger a ética e o direito.

$\mathrm{Ou}$ seja, a despeito dos diferentes métodos epistemológicos para auferir ambos os princípios e a possibilidade de questionamento quanto à sua universalidade, por ser possível questionar a concepção de racionalidade de Kant e indagar sobre a regra da indução utilizada por Bentham, a necessidade de universalidade que os princípios de ambas as teorias requerem as aproxima, em certo sentido. 
Tendo em vista as distintas origens dos princípios, torna-se possível depreender que o imperativo categórico (derivado exclusivamente da razão pura prática) requer que o agente suprima suas inclinaçóes e paixóes, quando segue a lei ética. Ao contrário, o princípio da utilidade reconhece que os homens agem de acordo com suas inclinaçôes e recomenda que assim ajam.

No que tange à ética, porém, a forma de coação é distinta para ambos os autores. Sobre esse tema, de acordo com Kant, o indivíduo que age eticamente, age de acordo com o imperativo categórico, motivado pela intenção de agir por dever, enquanto, no utilitarismo, segundo Bentham, o móbil da ação do indivíduo que age para maximizar o prazer de todos os afetados por sua ação não é necessariamente um incentivo interno, mas um incentivo externo, o qual constitui a aprovação ou desaprovação de um membro de destaque na comunidade.

Em outros termos, pode-se dizer que uma diferença importante entre ambas as teorias éticas é a motivação da ação, já que, enquanto o móbil da ação da teoria ética de Kant é o dever, a motivação da ação ética no utilitarismo de Bentham pode ser a aprovação ou desaprovaçáo que o indivíduo pode sofrer por um membro de destaque da comunidade ${ }^{24}$.

Por manterem relaçóes distintas com as respectivas noçóes de natureza humana, outra diferença entre essas teorias morais diz respeito ao que cada princípio ordena. O imperativo categórico ressalta ser reto agir apenas de acordo com uma lei que possa ser simultaneamente uma máxima lei universal e, para que essa ação seja ética, é necessário que a motivação seja o dever, sem que seja levada em conta a finalidade dessa ação. O princípio da utilidade, ao contrário, observa, em todos os casos, as consequências ou as finalidades das açôes. Qualquer ação deve produzir mais prazer do que dor, levando em conta todos os afetados por uma ação. Portanto, uma ação que pode ser proibida pela ética kantiana, como o mentir, por não poder ser uma máxima lei universal nesse esquema moral, pode ser permitida na teoria utilitarista, dependendo das consequências do ato.

Para examinar de forma correta quais serão as consequências das ações, Bentham sugere que é necessário conhecer, ao menos, as principais circunstâncias atinentes à ação. No caso específico do mentir, para saber se esse ato pode ser aprovado pelo princípio de utilidade, é preciso notar em

${ }^{24} \mathrm{O}$ indivíduo de Bentham também pode agir pensando na maximização de prazer para todos os afetados por uma ação, mas sua ação, para ser ética, não requer esse incentivo interno. 
quantas pessoas será gerado o prazer e a dor pelo ato ${ }^{25}$. Caso o cálculo, relativo ao ato de mentir, aponte para mais geração de prazer do que dor, consideradas determinadas circunstâncias, esse ato pode ser aprovado pelo princípio de utilidade. Contudo, se o ato apontar para a geração de mais dor do que prazer, será reprovado pelo princípio.

Sendo assim, é possível depreender que não há ação proibida no esquema utilitarista: são as circunstâncias e o cálculo entre prazer e dor que aprovarão ou desaprovarão determinada ação, em função de suas consequências, o que é totalmente oposto ao imperativo categórico, o qual aprova ou desaprova determinada ação, dependendo de sua possibilidade de universalização, tanto do ponto de vista ético quanto sob a ótica do direito.

Quanto ao direito, é possível afirmar que, para ambos os autores, a forma de coerção é a mesma, a saber: o uso da força. Todavia, os princípios que o embasam são distintos, conforme se argumentou. Para Kant, o princípio que embasa o direito é o imperativo categórico. Contudo, nesse domínio, não é necessário que o incentivo da ação seja o dever. É possível agir de acordo com leis jurídicas baseadas no imperativo categórico, sem que haja a necessidade de o indivíduo possuir como móbil da ação o dever. Para Bentham, o princípio que embasa o direito é o princípio da utilidade (princípio fundador de sua noção de moralidade e justiça). A fim de que se aja conforme o direito, de acordo com Bentham, não é necessário, também, que o agente considere todos os afetados por um ato, pois o indivíduo pode agir apenas levando em conta, em seu cálculo, as consequências da ação para si ou, em outros termos, o sofrimento que a aplicação da lei penal pode ocasionar, caso ele cometa uma ofensa.

Sobre as relações entre naçôes, é possível argumentar que ambos possuem um plano para a paz, mas seus respetivos argumentos para a conquista da paz são totalmente distintos. Enquanto Kant argumenta que a felicidade de um povo ou finalidade da política não deve ser levada em conta, mas antes as açóes entre naçôes devem ser reguladas pelo imperativo categórico (uma máxima lei que possa ser simultaneamente uma lei universal), Bentham ressalta, embasado em seu princípio de utilidade, que é fundamental levar em consideração a felicidade

\footnotetext{
${ }^{25}$ Além de observar a extensão ou o número de pessoas afetadas por uma ação, o cálculo entre prazer e dor sugere que a intensidade dos prazeres e dores, a duraçâo dos prazeres e dores, a certeza ou incerteza com que os prazeres e dores podem ser auferidos, a proximidade ou longinquidade com que podem ser obtidos, a fecundidade de cada prazer e dor e a pureza de cada prazer e dor sejam levados em consideração.
} 
ou finalidade das açôes entre naçóes, porque só assim seria possível efetuar um cálculo entre benefício e custo, prazer e dor, capaz de indicar que a manutenção da paz é mais vantajosa do que o estabelecimento da guerra.

Dessa maneira, considerando os princípios que embasam a ética, o direito e a relação entre naçóes, pode-se sustentar que, para Kant, é sempre o mesmo, qual seja; o imperativo categórico, assim como para Bentham também é sempre o mesmo, a saber: o princípio de utilidade. No entanto, seja quanto à origem epistemológica de ambos os princípios, seja no que concerne aos seus conteúdos ou ao incentivo que uma ação precisa ter para ser considerada ética, no esquema kantiano e no sistema utilitarista de Bentham, seja no que tange ao fundamento para formulaçáo de leis do direito ou ainda levando em conta a racionalidade que guia a relação entre naçóes, pode-se afirmar que ambas as teorias divergem quase que radicalmente. Os pontos comuns que podem ser atribuídos ao sistema de pensamento de Kant e Bentham, no que tange ao direito e à ética, são poucos e referem-se às aspiraçôes à universalidade de ambas as teorias, à necessidade de aplicação do uso da força como instrumento do direito, assinalando que, para que as leis jurídicas sejam seguidas, nos dois casos, não há necessidade de haver como incentivo interno o dever, conforme se demonstrou.

DIAS, Maria Cristina Longo Cardoso. Law and ethics in Bentham and Kant: a comparison. Trans/Form/Açāo, Marília, v. 38, n. 1, p. 147-166, Jan./Abr., 2015.

\begin{abstract}
The aim of this work is to formulate a comparison between Bentham's and Kant's conceptions of ethics and law. The position taken in this paper is that, for Bentham and Kant, law is grounded in the same principles which are the basis of ethics. For Kant it is the categorical imperative which is the basis of ethics, while the principle of utility is the basis of Bentham's theory of law and ethics. Although both authors have established only one principle on which to ground ethics and law, there are several differences between the two fields and between the theories of the two philosophers. Among these differences, we mention the epistemological origin of principles and their prescriptions.
\end{abstract}

KEYWORDS: Bentham. Duty. Law. Ethics. Kant. 


\section{REFERÊNCIAS}

BACHMANN, M.L. Kant's idea of peace and the philosophical conception of a world republic. In: BOHMAN, J.; BACHMANN, M.L. Perpetual Peace: essays on Kant's Cosmopolitan Ideal. New Baskerville: Massachusetts Institute of Technology Press, 1997. p. 58-75.

BENTHAM, J. A Table of the springs of action. Edinburgh: William Tait, 1843a. $\overline{1843 b .}$ . An Introduction to the principles of moral and legislation. Edinburgh: William Tait, Essay IV: a plan for an universal and perpetual peace. Edinburgh: William Tait, $1843 c$.

. Ensaio IV: um plano para uma paz universal e perpétua. Trad. Maria Cristina Longo Cardoso Dias e José Ignácio Coelho Mendes Neto. Brazilian Journal of International Relations, v. 1, n.1, 2012.

1973.

. Uma Introdução aos princípios da moral e da legislação. São Paulo: Abril Cultural,

BURNE, P. Bentham and the utilitarian principle. Mind, New Series, v. 58, n. 231, 1949.

BOBBIO, N. Direito e Estado no pensamento de Kant. Trad. Alfredo Fait. Brasília: UnB, 1995.

DIAS, M. C. L. C. A Medida da ética em Bentham. Cadernos de Ética e Filosofia Política, USP, v. 20, p. 6-21, 2012.

GOLDWORTH, A. Bentham's Concept of Pleasure: its relation to fictitious terms. Ethics, v. 82 , n. $4,1972$.

HART, L.A. H. Essays on Bentham: studies in jurisprudence and political theory. Oxford: Oxford University Press, 1982.

HECK, J. N. Direito e moral: duas lições sobre Kant. Goiânia: Editora UFG, 2000.

HOFFE, O. O Imperativo categórico do Direito: uma interpretação da Introdução da Doutrina do Direito. Studia Kantiana, v. 1, n.1, 1998.

KANT, I. Textos seletos. Petrópolis: Vozes, 1974.

. Crítica da Razão Pura. Trad. de Manuela Pinto dos Santos e Alexandre Fradique Morujão. Lisboa: Fundação Calouste Gulbenkian, 1989.

. Crítica da razáo prática. Lisboa: Edições 70, 1997.

. Fundamentação da metafísica dos costumes. Trad. de Paulo Quintela.

Lisboa: Ediçōes 70, 2001.

The Metaphysics of morals. Translated by Mary J. Gregor. Cambridge:

Cambridge University Press, 1991. 
NADAI, B. Teleologia e história em Kant: a ideia de uma história universal de um ponto de vista cosmopolita. 2006. Dissertação (Mestrado) - Faculdade de Filosofia Letras e Ciências Humanas da Universidade de São Paulo, São Paulo, 2006.

SINGER, M. Actual consequences of utilitarianism. Mind, Oxford, v. 86, n. 341, p. 67-77, Jan. 1977.

TERRA, R. R. Kant e o Direito. Rio de Janeiro: Jorge Zahar, 2004.

. História e Direito em 1784. Comentário sobre a interpretação da 'Escola Semântica de Campinas'. Studia Kantiana, Rio de Janeiro, v. 12, p. 175-194, 2012.

WARKE, T. A Reconstruction of classical utilitarianism. Journal of Bentham Studies, Londres, n. 3, 2000.

Recebido em: 01/10/14

Aceito em: 29/10/14 
DIAS, M. C. L. C. 